\section{Inheritance of Male Sterility in Japanese Apricot (Prunus mume)}

\author{
H. Yaegaki ${ }^{1}$, M. Miyake ${ }^{2}$, T. Haji, and M. Yamaguchi \\ Department of Breeding, National Institute of Fruit Tree Science, Ibaraki \\ 305-8605, Japan
}

Additional index words. breeding, gene-cytoplasmic male sterility, infertility, self-unfruitfulness

\begin{abstract}
Pollen fertility and inheritance patterns of male sterility were analyzed in various cultivars and selections of Japanese apricot (Prunus mume Sieb. et Zucc.). Male sterility segregated differently in two types of crosses. In pairings of male-sterile and male-fertile parents, progenies were either all male-fertile, all male-sterile, or mixed. Crossing two male-fertile plants resulted in offspring that were either all male-fertile or mixed. Male sterility in Japanese apricot appears to be of the gene-cytoplasmic type. The genotypes of 10 cultivars and three selections are determined.
\end{abstract}

Japanese apricot originated in southwest China and presently is one of the main fruit trees in Japan, where it has been cultivated from ancient times. Many cultivars are self-unfruitful; some are also male-sterile (Yaegaki et al., 2002a, 2002b), and fruit set can be adversely affected by meteorological conditions during the flowering period (February and March in Japan). Knowledge of the mode of inheritance of male sterility in Japanese apricot would be helpful in breeding self-fruitful cultivars, which will help to stabilize fruit production. However, the mechanisms of male sterility in Japanese apricot are presently not well established. Therefore, we analyzed pollen fertility and inheritance patterns in various cultivars, selections, and their progeny in order to determine the mode of inheritance of male sterility in Japanese apricot.

\section{Materials and Methods}

Two hundred sixty-six seedlings $(\approx 4-6$ years old) from 22 crosses of 14 cultivars and four selections of Japanese apricot, grown at the National Institute of Fruit Tree Science, Tsukuba, Japan, were examined (Tables 1 and 2). Pollen collected during the flowering periods from 1997 to 2002 was stored at -4 ${ }^{\circ} \mathrm{C}$ under desiccated conditions for $\approx 1$ month. Pollen samples were incubated for $\approx 12 \mathrm{~h}$ at 20 ${ }^{\circ} \mathrm{C}$ on $1 \%$ agar plates with a $10 \%$ sucrose solution, and germination rates were determined on 200 pollen grains in each sample. Pollen grains were considered germinated when pollen tube growth was longer than the diameter of the pollen grain. In male-sterile genotypes, pollen grains were small, shriveled, and did not germinate.

\footnotetext{
Received for publication 23 July 2002. Accepted for publication $24 \mathrm{Feb} .2003$.

${ }^{1}$ To whom requests for reprints should be addressed. E-mail address: yaegaki@affrc.go.jp

${ }^{2}$ Current address: Yamanashi Prefectural Fruit Tree
} Experiment Station, Yamanashi 405-0043, Japan mechanisms. It may be controlled by genes in the nucleus (genic male sterility), or by cyto- plasmic genes interacting with nuclear genes (gene-cytoplasmic male sterility) (Kaul, 1988). Male sterility in apricot (P.armeniaca L.) and peach $[P$. persica $(\mathrm{L}$.) Batsch.] is controlled by a single recessive gene in the nucleus (Burgos and Ledbetter, 1994; Hesse, 1975). However, our results indicate that the inheritance pattern of male sterility in Japanese apricot is genecytoplasmic. All 21 seedlings obtained from crossing 'Shirokaga' and 'Nankou' (i.e., MS × $\mathrm{MF}$ ), were male-sterile. In contrast, recovery of fertility was observed in seedlings obtained from the crossing 'Shirokaga' (MS) with 'Orihime' or 'Gessekai' (both MF). The 15 seedlings obtained from 'Nankou' $\times$ 'Juurou' (both MF) were all male-fertile. All 21 seedlings from the cross between 'Kagajizou' (MS) and 'Ume Tsukuba No. 4' (MF) were male-sterile, whereas all four seedlings from self-pollinated 'Ume Tsukuba No. 4' were male-fertile. Thus, it appears that male sterility in Japanese apricot is of the gene-cytoplasmic type.

Gene-cytoplasmic male sterility is common in higher plants (Kaul, 1988), and has been reported in the commercial fruit trees Citrus (Yamamoto et al., 1997) and olive (Besnard et al., 2000). Two genetic factors were responsible for gene-cytoplasmic male sterility (Kaul, 1988): "S," the cytoplasmic genome inducing male sterility, and "Rf," the nuclear genes that suppress the action of the cytoplasmic genome and promote normal pollen production. Male sterility is thought to be induced by the genotype (S)rfrf, i.e., a cytoplasmic genome favoring male sterility (S) together with homozygosity in the recessive nuclear gene rf. In the presence of the dominant nuclear fertility restoring gene (Rf) and/or the normal cytoplasmic genome (N), male fertility is recovered and normal pollen is produced.

The estimated genotypes of the gene-cytoplasmic male sterility model of cultivars and selections observed in this study are shown in Table 3. The genotypes of male-sterile cultivars, such as 'Shirokaga', 'Gyokuei', and 'Kagajizou', are presumed to be (S)rfrf.
Table 1. Male fertility, self-fruitfulness, and parentage of Japanese apricot cultivars and selections used in this study.

\begin{tabular}{llll}
\hline $\begin{array}{l}\text { Cultivars/ } \\
\text { selections }\end{array}$ & $\begin{array}{c}\text { Male } \\
\text { fertility }\end{array}$ & $\begin{array}{c}\text { Self- } \\
\text { fruitfulness }\end{array}$ & \multicolumn{1}{c}{ Parentage } \\
\hline Shirokaga & MS & SU & Unknown \\
Kagajizou & MS & SU & Shirokaga $\times$ Jizouume \\
Gyokuei & MS & SU & Unknown \\
Nankou & MF & SU & Unknown \\
Gessekai & MF & SU & Jyousyuushiro $\times$ Ohshuku \\
Baigou & MF & SU & Unknown \\
Kairyouuchidaume & MF & SU & Unknown \\
Gecchibai & MF & SU & Unknown \\
Juurou & MF & SU & Unknown \\
Ume Tsukuba No. $7^{x}$ & MF & SU & Gessekai $\times$ Baigou \\
Orihime & MF & SF & Unknown \\
Ryuukyoukoume & MF & SF & Unknown \\
Jizouume & MF & SF & Unknown \\
Hachirou & MF & SF & Jizouume open pollinated \\
Inazumi & MF & SF & Unknown \\
Ume Tsukuba No. $4^{x}$ & MF & SF & Jizouume open pollinated \\
Ume Tsukuba No. $9^{\mathrm{x}}$ & MF & SF & Orihime self-pollination \\
MM-38-16 & MF & SF & Youseiume self-pollination \\
\hline
\end{tabular}

${ }^{\mathrm{z}} \mathrm{MS}=$ male-sterile; $\mathrm{MF}=$ male-fertile.

${ }^{y} \mathrm{SU}=$ self-unfruitful; $\mathrm{SF}=$ self-fruitfulness

${ }^{\mathrm{x}}$ Selection is bred at the National Institute of Fruit Tree Science, Tsukuba, Japan. 
Table 2. Segregation of male-sterile/fertile seedlings from crosses of Japanese apricot.

\begin{tabular}{|c|c|c|c|c|c|c|c|c|c|}
\hline \multicolumn{2}{|c|}{ Cross combination } & $\begin{array}{c}\text { No. of } \\
\text { seedlings }\end{array}$ & $\begin{array}{c}\text { Male fertility } \\
\text { MS : MF }\end{array}$ & $\begin{array}{l}\text { Expected } \\
\text { ratio } \\
\end{array}$ & $\chi^{2}$ & $P$ & $\begin{array}{c}\text { Expected } \\
\text { ratio } \\
\end{array}$ & $\chi^{2}$ & $P$ \\
\hline \multicolumn{10}{|l|}{$\mathrm{MS} \times \mathrm{MF}$} \\
\hline \multirow[t]{6}{*}{ Shirokaga } & $\times$ Nankou & 21 & $21: 0$ & $1: 0$ & & & & & \\
\hline & × Ryuukyoukoume & 21 & $21: 0$ & $1: 0$ & & & & & \\
\hline & × Inazumi & 5 & $5: 0$ & $1: 0$ & & & & & \\
\hline & $\times$ Jizouume & 2 & $2: 0$ & $1: 0$ & & & & & \\
\hline & × Orihime & 6 & $0: 6$ & $0: 1$ & & & & & \\
\hline & × Gessekai & 3 & $0: 3$ & $1: 1$ & 3.000 & 0.08 & & & \\
\hline \multirow{5}{*}{ Kagajizou } & × Kairyouuchidaume & 25 & $25: 0$ & $1: 0$ & & & & & \\
\hline & $\times$ Ume Tsukuba No. 4 & 21 & $21: 0$ & $1: 0$ & & & & & \\
\hline & $\times$ MM-38-16 & 15 & $15: 0$ & $1: 0$ & & & & & \\
\hline & × Gecchibai & 20 & $10: 10$ & $1: 1$ & 0.000 & 1.00 & & & \\
\hline & × Ume Tsukuba No. 7 & 10 & $3: 7$ & $1: 1$ & 1.600 & 0.21 & & & \\
\hline Gyokuei & × Gessekai & 24 & $11: 13$ & $1: 1$ & 0.166 & 0.68 & $1: 3$ & 1.000 & 0.32 \\
\hline \multicolumn{10}{|l|}{$\mathrm{MF} \times \mathrm{MF}$} \\
\hline \multirow[t]{2}{*}{ Nankou } & × Juurou & 15 & $0: 15$ & $0: 1$ & & & & & \\
\hline & $\times$ Orihime & 4 & $0: 4$ & $0: 1$ & & & & & \\
\hline \multirow[t]{2}{*}{ Gessekai } & × Baigou & 8 & $2: 6$ & $1: 3$ & 0.000 & 1.00 & & & \\
\hline & × Nankou & 2 & $1: 1$ & $1: 1$ & 0.000 & 1.00 & & & \\
\hline \multirow[t]{2}{*}{ Baigou } & $\times$ Hachirou & 19 & $7: 12$ & $1: 1$ & 1.315 & 0.25 & $1: 3$ & 1.420 & 0.23 \\
\hline & $\times$ Orihime & 8 & $0: 8$ & $0: 1$ & & & & & \\
\hline Hachirou & $\times$ Ume Tsukuba No. 9 & 20 & $0: 20$ & $0: 1$ & & & & & \\
\hline Ume Tsukuba No. 4 & × Juurou & 5 & $0: 5$ & $0: 1$ & & & & & \\
\hline Ume Tsukuba No. 4 & Self pollination & 4 & $0: 4$ & $0: 1$ & & & & & \\
\hline Orihime & Self pollination & 8 & $0: 8$ & $0: 1$ & & & & & \\
\hline
\end{tabular}

Table 3. Cytoplasmic and nuclear genotype of Japanese apricot cultivars and selections used in this study.

\begin{tabular}{|c|c|}
\hline $\begin{array}{l}\text { Cytoplasmic and } \\
\text { nuclear gene type }\end{array}$ & Cultivars/selections \\
\hline (S)rfrf & Shirokaga, Kagajizou, Gyokuei \\
\hline (S)Rfrf & Gessekai, Baigou, Ume Tsukuba No. 7 \\
\hline (N)rfrf & $\begin{array}{l}\text { Nankou, Kairyouuchidaume, Ryuukyoukoume, Inazumi, Hachirou } \\
\text { Ume Tsukuba No. 4, MM-38-16 }\end{array}$ \\
\hline$(\mathrm{N}) \mathrm{rf}-$ & Jizouume \\
\hline$(-) \operatorname{RfRf}$ & Orihime, Ume Tsukuba No. 9 \\
\hline$(-)$ Rfrf & Gecchibai \\
\hline Unknown & Juurou \\
\hline
\end{tabular}

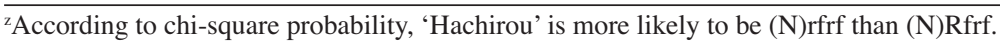

The nuclear genes in the male-fertile cultivars and selections 'Nankou', 'Ryuukyoukoume', 'Kairyouuchidaume', 'Inazumi', 'Ume Tsukuba No. 4', and 'MM-38-16' probably are rfrf, since these cultivars and selections produced only male-sterile seedlings when crossed with the male-sterile cultivars and selections. Since they are male-fertile, they do not seem to possess the cytoplasmic male sterility factor, and can therefore be denoted (N)rfrf.

'Gessekai' and 'Baigou' carry the male sterility factor in the cytoplasm and are heterozygous in their fertility restoring genes denoted (S)Rfrf, because both male-sterile and fertile seedlings were produced in crosses with 'Gessekai' and 'Baigou' as female and/ or male parents. The genetic constitution of 'Ume Tsukuba No. 7', a selection derived from 'Gessekai' $\times$ 'Baigou', is also (S)Rfrf, because the progenies obtained from crossing 'Ume Tsukuba No. 7' with the male-sterile 'Kagajizou' segregated into male-sterile and fertile plants. Progenies of 'Shirokaga' $\times$ 'Orihime' and 'Baigou' $\times$ 'Orihime' were all male-fertile. Thus, 'Orihime' must be homozygous in the fertility restoring gene (i.e., RfRf), but its cytoplasmic factor is unknown. If so, 'Ume Tsukuba No. 9', which is derived from selfpollination of 'Orihime', must also carry RfRf. The inheritance pattern of 'Gecchibai' indicates the presence of heterozygous fertility restoring genes (Rfrf), because progenies derived from 'Gecchibai' pollen segregated into male-sterile and fertile seedlings. The cytoplasmic factor of 'Gecchibai' is unknown. The genotype of 'Jizouume', the female parent of 'Ume Tsukuba No. 4', must include the normal cytoplasmic factor $(\mathrm{N})$ and at least one recessive nuclear gene. The progenies of the cross between pollen of 'Hachirou', which originated from the natural pollination of 'Jizouume', and 'Baigou' as female parent, segregated into seven malesterile seedlings and 12 male-fertile ones. This is closer to a ratio of 1:1 than 1:3 (Table 2), and we infer that the genotype of 'Hachirou' is more likely to be (N)rfrf than (N)Rfrf.
In summary, inheritance patterns and the genotypes of male sterility were determined in several cultivars and selections of Japanese apricot. It is concluded that male sterility is of the nuclear-cytoplasmic type in this species. These investigations are continuing in order to produce new self-fruitful cultivars of Japanese apricot.

\section{Literature Cited}

Besnard, G., B. Khadari, P. Villemur, and A. Berville. 2000. Cytoplasmic male sterility in the olive (Olea europaea L.) Theor. Appl. Genet. 100:1018-1024.

Burgos, L. and C.A. Ledbetter. 1994. Observations on inheritance of male sterility in apricot. HortScience 29:127.

Hesse, C.O. 1975. Peaches, p. 285-335. In: J. Janick and J.N. Moore (eds.). Advances in fruit breeding. Purdue Univ. Press, West Lafayette, Ind.

Kaul, M.L.H. 1988. Male sterility in higher plants. Springer-Verlag, Berlin, Heidelberg.

Yaegaki, H., T. Haji, and M. Yamaguchi. 2002a. Cultivar differences of pollen quantity, rate of stained pollen and rate of germinated pollen in Japanese apricot (Prunus mume Sieb. et Zucc.) cultivars. Bul. Natl. Inst. Fruit Tree Sci. 1:47-53.

Yaegaki, H., M. Miyake, T. Haji, and M. Yamaguchi. 2002b. Determination of self-fruitfulness in Japanese apricot (Prunus mume Sieb. et Zucc.) cultivars. Bul. Natl. Inst. Fruit Tree Sci. 1:55-60.

Yamamoto, M., R. Matsumoto, N. Okudai, and Y. Yamada. 1997. Aborted anthers of Citrus result from gene-cytoplasmic male sterility. Scientia Hort. 70:9-14. 